\title{
Management of recurrent rectal prolapse
}

\section{Postępowanie w nawrotowym wypadaniu odbytnicy}

\author{
Tomasz Kościński, Jacek Hermann, Tomasz Banasiewicz \\ Department of General Surgery, Gastrointestinal Oncologic Surgery and Plastic Surgery, Poznan University of Medical \\ Sciences, Poland
}

Prz Gastroenterol 2013; 8 (4): 243-246 DOI: $10.5114 / p g .2013 .37486$

Key words: recurrent rectal prolapse, redo surgery, abdominal rectopexy.

Słowa kluczowe: nawrotowe wypadanie odbytnicy, operacje wtórne, rektopeksja brzuszna.

\begin{abstract}
Address for correspondence: Tomasz Kościński MD, PhD, Department of General Surgery, Gastrointestinal Oncologic Surgery and Plastic Surgery, Poznan University of Medical Sciences, 49 Przybyszewskiego St, 60-355 Poznan, Poland, phone: +48 618691275 , fax: +48 6186916 84, e-mail: tomaszkoscinski.proktolog@op.pl
\end{abstract}

\begin{abstract}
Aim: Evaluation of results of the redo operations performed for recurrent rectal prolapse.

Material and methods: This study entered 16 patients after redo surgery for recurrent rectal prolapse between 1998 and 2010. There were 14 female and 2 male patients aged from 42 to 92 (mean age 69 years). Primary abdominal rectopexy was performed in 5 patients, 3 patients underwent perineal rectosigmoidectomy, 1 patient had abdominal sigmoidectomy, Delorme procedure was applied in 2 patients, Thiersch encirclement in 4 patients and perineoplasty in 1 patient. There were redo operations for recurrent prolapse as follows: abdominal rectopexy in 7 patients, perineocolporectopexy in 3 females, rectopexy with sigmoidectomy in 2 patients, Altemeier operation in 7 patients and Longo procedure in 1 patient.

Results: Permanent correction of prolapse was successful in $12(75 \%)$ patients. Following relapses were recognized in $3 \mathrm{pa}-$ tients who underwent Altemeier operation and in 1 patient after the Longo procedure. There were no statistically significant differences regarding faecal incontinence and obstructed defecation between the patients before and after the operation. Conclusions: Abdominal rectopexy is the method of choice for the treatment of recurrent rectal prolapse. Rectopexy combined with correction of associated anatomical defects of the pelvic floor results in a better functional outcome. Redo operations with the perineal approach are burdened with a high rate of recurrence.
\end{abstract}

\section{Streszczenie}

Cel: Ocena wyników leczenia nawrotowego wypadania odbytnicy.

Materiał i metody: Przebadano 16 pacjentów, którzy byli operowani z powodu nawrotowego wypadania odbytnicy w latach 1998-2010. Do badania włączono 14 kobiet i 2 mężczyzn w wieku 42-92 lat (średnia 69 lat). Pierwotnie brzusznej rektopeksji poddano 5 pacjentów. Jeden z nich przebył wycięcie esicy z dostępu brzusznego, natomiast pozostali zostali zakwalifikowani do operacji z dostępu kroczowego. Rektosigmoidektomię wykonano u 3 chorych, operację sposobem Delorma u 2 chorych, zabieg sposobem Thierscha u 4 pacjentów i plastykę krocza u 1 chorego. Nawrót choroby leczono rektopeksją brzuszną u 7 pacjentów, umocowanie krocza, pochwy i odbytnicy z wszczepem siatkowym wykonano u 3 kobiet, rektopeksję brzuszną z resekcją esicy przeprowadzono u 2 chorych, operację sposobem Altemeiera u 7 pacjentów i zabieg sposobem Longo u 1 osoby.

Wyniki: Trwałe umocowanie odbytnicy uzyskano w 12 przypadkach (75\%). Kolejne nawroty wypadania zaobserwowano u 3 pacjentów operowanych sposobem Altemeiera i u 1 chorego poddanego wcześniej operacji sposobem Longo. Pacjenci przed leczeniem operacyjnym i po nim nie różnili się istotnie zarówno pod względem nietrzymania, jak i trudności w wydalaniu stolca.

Wnioski: Rektopeksja brzuszna jest metoda z wyboru u pacjentów zakwalifikowanych do leczenia chirurgicznego z powodu nawrotowego wypadania odbytnicy. Połączenie rektopeksji brzusznej z terapią innych chorób struktur dna miednicy umożliwia uzyskanie lepszego wyniku czynnościowego. Leczenie nawrotu wypadania odbytnicy z dostępu kroczowego często prowadzi do kolejnych nawrotów choroby. 


\section{Introduction}

Permanent anatomical correction of the structural defect and optimal functional result are the principal purposes of the surgical treatment of rectal prolapse $[1,2]$. Although the rate of recurrence rises to $50 \%$ of patients, on the basis of the literature, there are limited data regarding the possible causal factors of relapse and the treatment options available [3-5]. Abdominal fixation of the rectum to the promontory and anterior resection of the rectum and sigmoid colon, or a combination of both, are the most efficient methods of primary treatment of the disease, though in low-risk patients [1]. In turn, perineal rectosigmoidectomy, mucosal sleeve resection, or anal encirclement is recommended in high-risk groups of patients. Surgical technique applied to primary surgery may influence the choice of redo operation [6]. Postoperative, persistent constipation in the form of obstructed defecation with excessive straining is one of the most important causes of recurrence. Anatomical defects such as deep pouch of Douglas, hypotonicity or atrophy of the anal sphincters, loose pelvic ligamentous structures attached to the rectum and dolichocolon are additional causal factors of relapse. Primary operations for rectal prolapse should be

Table I. Diseases and structural defects of the pelvic floor associated with rectal prolapse

Tabela I. Zmiany patologiczne towarzyszace wypadaniu odbytnicy

\begin{tabular}{lc} 
Defects & Number \\
\hline Enterocele & 14 \\
\hline Utero-vaginal prolapse & 5 \\
\hline Descending pelvic floor & 5 \\
\hline Rectocele & 4 \\
\hline Diverticulosis of the colon & 3 \\
\hline Cystocele & 1 \\
\hline Abdominal hernia & 1
\end{tabular}

Table II. Methods of primary surgery in patients with rectal prolapse

Tabela II. Pierwotne sposoby leczenia chirurgicznego chorych z nawrotami wypadania odbytnicy

\begin{tabular}{lc} 
Method & Number \\
\hline Abdominal rectopexy & 5 \\
\hline Perineal rectosigmoidectomy & 3 \\
\hline Delorme operation & 2 \\
\hline Abdominal rectosigmoidectomy & 1 \\
\hline Perineoplasty & 1 \\
\hline Thiersch operation & 4
\end{tabular}

combined with correction of associated structural defects of the pelvic floor such as enterocele, pelvic floor descent as well as utero-vaginal prolapse $[3,4]$.

\section{Aim}

The aim of this study was to evaluate the results of redo operations performed for recurrent rectal prolapse.

\section{Material and methods}

Medical records of 16 patients who underwent redo surgery for recurrent rectal prolapse at the Department of General Surgery, Gastrointestinal Oncologic Surgery and Plastic Surgery in Poznań between 1998 and 2010 were retrospectively evaluated. There were 14 female and 2 male patients aged from 42 to 92 . The mean age was 69 years. This study was entered by 11 patients operated on in the authors' hospital whereas 7 patients underwent surgery in different county hospitals. What is more, 4 females have been operated on due to rectal prolapse twice before. A laparoscopic approach was not used in this study. Prolapse was associated in some patients with other diseases and structural defects of the pelvic floor appearing in varied configurations (Table I). Methods of the primary operation followed by relapse are specified in Table II. Recurrent prolapse also occurred in 5 patients after abdominal rectopexy with a mesh. That accounted for $10 \%$ of all patients in whom that method was used at the authors' hospital. A nonabsorbable polypropylene monofilament mesh was applied in 2 patients from that group whereas an absorbable polyglycolic acid mesh was used in others. Abdominal resection of the rectum and sigmoid colon was performed in 1 patient, whereas perineal rectosigmoidectomy was performed in 3 females. In turn, rectal wall plication according to Delorme was used in 2 patients. Thiersch anal encirclement was implemented in 4 patients. Recurrence of rectal prolapse occurred between 1 and 60 months after the primary operation. The average period of time was 18 months. All the patients were diagnosed with digital rectal examination and rectoscopy before surgery. Oedema and thickening of the rectal mucosa were recognized in 12 patients whereas solitary rectal ulcer occurred in 1 female. Defecography was performed in 8 patients and it showed descending pelvic floor, utero-vaginal prolapse and enterocele in 3 of them. Anorectal manometry was undertaken in $6 \mathrm{pa}-$ tients. All patients remained under surveillance at the out-patient department attached to the authors' clinic.

\section{Statistical analysis}

Bowel signs such as faecal incontinence and dysfunction defecation before and after the operation were 
evaluated statistically with the Mann-Whitney test of significance to compare nonparametric data. The difference was accepted as non-significant at $p>0.05$.

\section{Results}

Abdominal rectopexy with a non-absorbable polypropylene monofilament mesh was the most common redo operation for recurrent rectal prolapse. That procedure was performed in 12 patients. The method was combined with resection of the redundant sigmoid colon in 2 of them due to persistent constipation with excessive straining, and with perineocolporectopexy together with recto-vaginal septum reconstruction due to descending pelvic floor and enterocele in 3 of the patients. In 6 patients abdominal rectopexy was performed due to failure of the perineal procedures. Subsequent relapses did not occur. Technical details of aforementioned operations were included in the authors' previous publication [7].

Perineal procedures were implemented in a highrisk group of patients with the mean age of 80 years. They underwent perineal resection of the protruding rectum and sigmoid colon with colo-anal anastomosis. Three of the patients were operated on twice or three times for recurrent prolapse with the perineal approach. If a symptomatic sphincter defect presenting with faecal incontinence was demonstrated, an overlapping procedure was considered (Table III).

There were no statistically significant differences between the patients before and after the operation regarding severe faecal incontinence and the rate of bowel movements (Table IV).

Surgical and general complications of redo operations for recurrent rectal prolapse are specified in Table V. Subsequent relapses of the disease occurred in 4 patients operated on with the perineal approach exclusively. That accounted for $50 \%$ of all patients undergoing a perineal procedure. The Altemeier operation was used in 3 of them while the Longo operation was used in 1 female.

\section{Discussion}

Pathogenesis of rectal prolapse is not well understood at this time. The role of excessive straining, leading to or associated with hypotonicity and atrophy of the muscular and fascial structures of the pelvic floor, and as a result perineal descent, obstructed defecation and constipation, is not entirely clear. Aforementioned factors should have been taken into account before making a decision regarding the appropriate operation method. The aim of that operation is to obtain permanent adhesions between the rectum and surrounding pelvic tissues resistant to excessive defecation straining.
Table III. Redo operations for recurrent rectal prolapse $(n=20)$

Tabela III. Operacje naprawcze nawrotowego wypadania odbytnicy $(n=20)$

\begin{tabular}{ll} 
Abdominal approach & \\
\hline Abdominal rectopexy with mesh & 7 \\
\hline Abdominal rectopexy with sigmoidectomy & 2 \\
\hline Perineocolporectopexy & 3 \\
\hline Perineal approach & 7 \\
\hline Altemeier operation with sphincter reconstruction & 1
\end{tabular}

Table IV. Bowel signs $(n=16)$

Tabela IV. Występowanie objawów jelitowych $(n=16)$

\begin{tabular}{lccc} 
Sign & $\begin{array}{c}\text { Before } \\
\text { operation }\end{array}$ & $\begin{array}{c}\text { After } \\
\text { operation }\end{array}$ & $\begin{array}{c}\text { Value of } \\
p\end{array}$ \\
\hline Faecal incontinence & 7 & 4 & 0.31 \\
\hline Outlet obstruction & 6 & 4 & 0.734
\end{tabular}

Table V. Complications of redo operations for recurrent rectal prolapse

Tabela V. Powikłania operacji naprawczych nawrotowego wypadania odbytnicy

\begin{tabular}{lc} 
Complication & Number \\
\hline Successive rectal prolapse & 4 \\
\hline Mucosal rectal prolapse & 2 \\
\hline Ventral hernia & 1 \\
\hline Depression & 1 \\
\hline Encephalitis & 1 \\
\hline Myocardial infarction & 1 \\
\hline Death (liver cirrhosis) & 1
\end{tabular}

Development of recurrent prolapse of the rectum is gradual in most cases. The mean period of time to recurrence ranges between 24 and 33 months with up to one third of cases occurring within the first 7 months after primary repair $[4,5]$.

It is widely accepted that pathophysiological factors regarding treatment of rectal prolapse are taken into account during abdominal methods of operation [3, 4, 8]. Relapses after abdominal procedures more likely result from technical faults such as the use of absorbable meshes for repair $[9,10]$.

A group of 12 (75\%) patients from the surveyed group of 16 patients required a single redo operation for recurrence of rectal prolapse. 
Faecal incontinence improves after surgical repair of rectal prolapse, and this improvement may extend for up to 6 months. This allows the chronically dilated sphincter to regain its normal structure and function. Patients suffering from recurrent prolapse may develop damage to the pudendal nerves and the anal sphincter complex [11]. Therefore, successive manometric testing in patients with recurrent disease suggests that faecal incontinence may persist [4]. In turn, patients after primary surgery for rectal prolapse show improvement in bowel control in $50 \%$ to $70 \%$ of cases [1].

Operations with the perineal approach enable resection of the protruding bowel as well as anal sphincter repair. The risk of recurrence may rise if the muscular and fascial structures of the pelvic floor are not reinforced, if a deep pouch of Douglas is not obliterated, and due to decreased propensity to adhesions between the rectum and the pelvic tissues as well [12]. The ischaemic segment of a bowel should not be left intact in the operating field if another repair with a perineal approach is undertaken in a case of multiple recurrences [4-7]. The recurrence rate after operations with a perineal approach according to the authors' experience reached $50 \%$ of patients. For instance, Steele reported a $37.3 \%$ rate of relapse [5]. Therefore, an abdominal procedure should be considered until laparotomy is not contraindicated due to poor general condition of a patient.

\section{Conclusions}

Abdominal rectopexy is the treatment of choice for recurrent rectal prolapse. Rectopexy combined with correction of associated anatomical defects of the pelvic floor results in a better functional outcome. Redo operations with the perineal approach are burdened with a high rate of recurrence.

\section{References}

1. Karulf RE, Madoff RD, Goldberg SM. Rectal prolapse. Curr Probl Surg 2001; 38: 771-832.

2. Raftopoulos Y, Senagore AJ, Di Giuro G, Bergamaschi R; Rectal Prolapse Recurrence Study Group. Recurrence rates after abdominal surgery for complete rectal prolapse: a multicenter pooled analysis of 643 individual patient data. Dis Colon Rectum 2005; 48: 1200-6.

3. Fengler SA, Pearl RK, Prasad ML, et al. Management of recurrent rectal prolapse. Dis Colon Rectum 1997; 40: 832-4.

4. Hool GR, Hull TL, Fazio VW. Surgical treatment of recurrent complete rectal prolapse: a thirty-year experience. Dis Colon Rectum 1997; 40: 270-2.

5. Steele SR, Goetz LH, Minami S, et al. Management of recurrent rectal prolapse: surgical approach influences outcome. Dis Colon Rectum 2006; 49: 440-5.

6. Kościński T, Stadnik H. Surgical treatment of recurrent rectal prolapse-own experience. Polish J Surg 2006; 78: 757-65.
7. Kościński T, Stadnik H. Surgical treatment of rectocoele as the most common cause of rectal voiding disturbances-own experience with the use of prosthetic material. Pol J Surg 2010; 82: 988-1000.

8. Bianco V, Bhonanno GM, Picardo G, et al. Recurrent rectal prolapse. Second Joint Meeting of ECCP and EACP. Bologna 2005, Abstract Book-Tech Coloproctol P47, 92.

9. Galili Y, Rabau M. Comparison of polyglycolic acid and polypropylene mesh for rectopexy in the treatment of rectal prolapse. Eur J Surg 1997; 163: 445-8.

10. Kościński T, Meissner W, Stadnik H. Abdominal rectopexy with absorbable and non-absorbable materiale in the treatment of recital prolapse. Pol J Surg 2011; 83: 1233-40.

11. Duthie GS, Bartolo DC. Abdominal rectopexy for rectal prolapse: a comparison of techniques. Br J Surg 1992; 79: 107-13.

12. Brown AJ, Anderson JH, McKee RF, Finlay IG. Strategy for selection of type of operation for rectal prolapse based on clinical criteria. Dis Colon Rectum 2004; 47: 103-7. 